\title{
De religieuze beleving van moslims in Nederland
}

\section{Diversiteit en verandering in beeld}

\author{
Willem Huijnk*
}

\section{Summary}

This article gives an overview of the main findings of a report published by the Netherlands Institute for Social Research which describes how different Muslim groups experience and practice their religion, and what developments have taken place over time. A typology - based on a latent class analysis - is used to explore religious diversity among Muslims in the Netherlands. The study shows that religion plays an important role in the lives of virtually all Muslims. The way in which Muslims experience their religion is changing, but the direction of change is not uniform. There is a mild secularisation trend among the Turkish Dutch; the percentage who regard themselves as non-religious is small but has grown. This is not the case for the Moroccan Dutch, virtually all of whom identify as Muslim. At the same time, religiosity has increased among both Turkish and Moroccan Muslims.

\section{Moslims in Nederland: diversiteit en verandering}

De islam is na het christendom in Nederland en Europa de grootste godsdienst. Van de Nederlanders van 15 jaar en ouder geeft ongeveer $6 \%$ aan moslim te zijn. ${ }^{1}$ Dit betekent dat er om en nabij de 1 miljoen moslims wonen in Nederland. Weinig onderwerpen zijn de laatste jaren zo veel en verhit bediscussieerd als de islam en de positie van moslims. In de overwegend seculiere Nederlandse samenleving worden moslims sinds begin deze eeuw steeds prominenter geconfronteerd met anti-islamitische geluiden.

In dit artikel ${ }^{2}$ gaan we allereerst in op hoe verschillende moslimgroepen in Nederland, met name die van Marokkaanse en Turkse herkomst, hun geloof beleven en belijden. Over moslims wordt in het publieke debat regelmatig generaliserend gesproken; het moslim-zijn wordt gezien als allesbepalend voor het individuele handelen, en verschillen tussen moslims worden

* Willem Huijnk is wetenschappelijk onderzoeker op het gebied van integratie, migratie en diversiteit bij het Sociaal en Cultureel Planbureau (SCP). Hij richt zich onder meer op de arbeidsmarkt- en sociaal-culturele positie van migranten. 
nauwelijks benoemd (Wagemakers \& De Koning 2015). We gaan wél in op de verscheidenheid onder moslims, onder meer door na te gaan of er categorieën van moslims te onderscheiden zijn op basis van hun gedrag, opvattingen en identificatie. Door religie in het algemeen en de islam in het bijzonder te beschouwen als multidimensionaal of gelaagd, gaan we verder dan het dichotome onderscheid in moslims en niet-moslims, in religieus en seculier, en kunnen we dieper ingaan op ontwikkelingen als secularisering of religionisering (of religieuze vitalisering).

$\mathrm{Na}$ het beschrijven van de verscheidenheid gaan we dan ook in op mogelijke veranderingen in de religieuze beleving van moslims in Nederland. Het dominante beeld bij het christendom is dat van een ontkerkelijking, die zich over een breed front manifesteert (De Hart 2014). Het beeld bij moslims is anders. Alhoewel in de Moslim in Nederland-studie uit 2004 onder moslims ook een trend naar secularisering werd gesignaleerd (Phalet \& Ter Wal 2004), liet de Moslim in Nederland-studie uit 2012 (Maliepaard \& Gijsberts 2012) andere ontwikkelingen zien. De identificatie met het geloof was onverminderd hoog, ook onder de tweede generatie. Bij hen was er juist een toename in het moskeebezoek. Voor veel Turkse en Marokkaanse Nederlanders nam de islam, ook in de Nederlandse seculiere context, een belangrijke plaats in hun leven in.

In dit artikel kijken we zowel naar de ontwikkelingen in het deel van de Marokkaanse en Turkse Nederlanders dat zich moslim noemt, als naar ontwikkelingen in de wijze waarop Marokkaanse en Turkse moslims hun geloof belijden. Ook komen verschillen tussen de eerste en tweede generatie ${ }^{3}$ aan bod. We pogen de gesignaleerde ontwikkelingen te duiden aan de hand van theoretische inzichten. Tegelijkertijd zij opgemerkt dat het buiten het bestek van dit onderzoek gaat om deze verklaringen ook direct te toetsen.

\section{Een studie naar moslims in Nederland; methodologie en onderzoekspopulatie}

In Nederland wordt de moslimgemeenschap voor het overgrote deel gevormd door migranten en hun kinderen. Het aantal moslims zonder migratieachtergrond is zeer klein. In 2014 werd het aantal autochtone moslims geschat op 13.000 (Schmeets \& Van Mensfoort 2015). Dit betreft zowel bekeerde autochtone Nederlanders als kinderen van tweede-generatiemigranten (de derde generatie). 
De onderzoeksvragen in deze studie worden beantwoord aan de hand van diverse edities van de Survey Integratie Migranten (SIM). ${ }^{4}$ De SIM's zijn uitgevoerd om inzicht te krijgen in de leefsituatie, posities en houdingen van de grootste vier niet-westerse migrantengroepen (Turkse, Marokkaanse, Antilliaanse en Surinaamse Nederlanders). Aan deze groepen en aan een vergelijkingsgroep van autochtone Nederlanders zijn vragen gesteld over onder meer onderwijs, arbeid, sociale contacten, culturele integratie, godsdienst, beeldvorming en gezondheid. In de SIM'15 zijn naast de hiervoor genoemde groepen ook Somalische en Poolse Nederlanders bevraagd.

In totaal is er informatie over 7249 moslims uit 2006, 2011 of 2015. In het SIM-onderzoek zijn in de diverse jaargangen verschillende respondenten ondervraagd (cross-sectioneel onderzoek). Het is dus geen panel-onderzoek, waardoor geen 'harde' uitspraken over individuele ontwikkelingen gedaan kunnen worden. Wel krijgen we een beeld van hoe ontwikkelingen op het niveau van de groep eruit zien. Het onderzoek is niet in alle jaargangen exact hetzelfde geweest. Tussen 2006 en 2011 hebben de grootste veranderingen plaatsgevonden. In 2011 zijn er naast de face-to-face-interviews ook telefonisch en via het web respondenten geïnterviewd. Ook is er in 2011 meer gewerkt met enquêteurs uit eigen etnische kring. Tussen 2011 en 2015 is er niet veel veranderd in de onderzoeksopzet. De respons varieerde in 2006 van minimaal $46 \%$ bij de Surinaamse Nederlanders tot $60 \%$ bij de Turkse Nederlanders. In de SIM uit 2006 was de response rate bij de Surinaamse Nederlanders (43\%) het minst hoog en bij de Turkse groep (54\%) het hoogst. In 2015 varieerde de response rate van $37 \%$ bij de Somalische Nederlanders tot $51 \%$ bij de Turkse Nederlanders.

De focus ligt in dit artikel op de periode 2006-2015, omdat de beschikbare gegevens over deze periode het beste onderling vergelijkbaar zijn. Hierbij is er vooral veel informatie over de twee grootste moslimgroepen in Nederland, de Turks-Nederlandse moslims en Marokkaans-Nederlandse moslims. ${ }^{5} \mathrm{Zij}$ vormen samen ongeveer twee derde van de moslims in Nederland. Daarnaast noemt circa één op de tien van de Surinaamse Nederlanders zich moslim (Maliepaard \& Gijsberts 2012).

\section{Algemene beschrijving van moslims; geen focus op radicale subgroepen}

Het onderzoek is gericht op een beschrijving van de groep moslims in haar geheel en niet op radicale subgroepen, niet in de laatste plaats omdat de data (en methode) zich daar simpelweg niet voor lenen. Daarnaast richt relatief veel onderzoek zich op die aspecten van religiositeit van moslims die als problematisch worden ervaren door politici of opiniemakers (Sunier 2009). Dit 
soort onderzoek is relevant en belangrijk, maar belicht tegelijkertijd alleen de problematische kanten van de islam. Dit onderzoek gaat ook niet diep in op heel specifieke orthodoxe praktijken, geloofsopvattingen of stromingen, zoals het salafisme. ${ }^{6}$

\section{De religiositeit van moslims in beeld}

Voor een goed beeld van de religiositeit van moslims is het van belang om meerdere aspecten te belichten; religie is immers een multidimensionaal fenomeen (Stark \& Glock 1968). Dit betreft zowel zichtbare aspecten of gedragingen (het praktiseren), als houdingen en vormen van religieuze identificatie. De religieuze prakijken kunnen in de privé- of publieke ruimte worden uitgeoefend. We beschrijven aan de hand van een aantal indicatoren kort de religieuze beleving van de twee grootste moslimgroepen in Nederland, die met een Turkse of Marokkaanse herkomst (zie tabel 1).7 Ondanks dat we diverse kanten van de religiositeit belichten, blijven er vanzelfsprekend onderwerpen onaangeroerd, zoals bijvoorbeeld specifieke vragen over geloofsinhoud en -voorstellingen (De Koning 2012; Ajouaou 2015).

\section{Tabel 1 Religieus gedrag en religieuze houdingen onder moslims, 15 jaar en ouder, naar herkomst, 2015 (in procenten)}

\begin{tabular}{lcc}
\hline & Turks & Marokkaans \\
\hline ziet zichzelf als moslim $^{\mathrm{a}}$ & 86 & 94 \\
niet-geloviga $^{\mathrm{a}}$ & 10 & 5 \\
bezoekt minimaal eenmaal per week de moskee & 40 & 37 \\
bidt elke dag vijfmaal & 33 & 78 \\
heeft alle dagen gevast tijdens de ramadan & 55 & 87 \\
eet iedere dag halal & 80 & 93 \\
draagt een hoofddoek (vrouwen) & 49 & 78 \\
mijn geloof is een belangrijk deel van mijzelf & 89 & 96 \\
het is vervelend als je dochter trouwt met iemand van een ander geloof ${ }^{b}$ & 60 & 63 \\
moslims moeten leven volgens de regels van de islam $^{b}$ & 61 & 66 \\
\hline
\end{tabular}

a Dit betreft het aandeel onder de totale bevolkingsgroep; de overige indicatoren in de tabel gaan uitsluitend over moslims.

b Het aandeel dat het (helemaal) eens is met de stelling.

Bron: SCP (SIM'15)

Een zeer groot deel van de Turkse (86\%) en Marokkaanse (94\%) Nederlanders beschouwt zich als moslim. Het aandeel niet-gelovigen is bij de Turkse groep (10\%) groter dan bij de Marokkaanse groep (5\%). Voor bijna alle moslims neemt 
het geloof een belangrijke plaats in. Tegelijkertijd is er ook diversiteit. Deze pluriformiteit loopt onder andere via etnische scheidslijnen. Marokkaanse moslims bidden aanzienlijk vaker dan Turkse moslims: van de Marokkaanse moslims bidt ruim driekwart (78\%) vijfmaal per dag, bij de Turkse moslims is dit een derde (33\%). Tegelijkertijd geeft ook het merendeel van de Turkse moslims aan tenminste wekelijks te bidden. Het deel dat ten minste wekelijks naar de moskee gaat is onder Turkse en Marokkaanse moslims ongeveer even groot (resp. 40\% en 37\%). Een zeer groot deel van de moslims eet (bijna) altijd halal: bij de Marokkaanse moslims doet 93\% dit, bij de Turkse moslims 80\%. Het overgrote deel van de Marokkaanse moslims (87\%) vast alle dagen tijdens de ramadan; bij de Turkse moslims is dit iets meer dan de helft (55\%). Van de Marokkaanse moslima's draagt een groter deel (78\%) een hoofddoek dan van de Turkse moslima's (49\%). Onder beide groepen geeft een zeer groot deel van de Marokkaanse (96\%) en Turkse (89\%) moslims aan dat het geloof een (zeer) belangrijk deel is van henzelf. De verschillen in religieuze opvattingen, bijvoorbeeld ten aanzien van de rol van het geloof in de politiek, gemengd huwen of het leven volgens de regels van de islam, zijn tussen Turkse en Marokkaanse moslims gering.

Op veel terreinen is de tweede generatie wat minder religieus dan de eerste. Een groter deel is niet-gelovig, bid minder vaak, draagt minder vaak een hoofddoek en bij de Marokkaanse tweede generatie is het moskeebezoek lager. Tegelijkertijd is ook voor een groot deel van de tweede generatie het geloof zeer belangrijk.

\section{Profielen van moslims in Nederland}

Een doel van dit artikel is om de gelaagdheid van de religieuze beleving van moslims in kaart te brengen. Dit kan onder meer aan de hand van een latenteklasseanalyse. Een latenteklasseanalyse is een systematische, empirische manier om personen in te delen in homogene groepen, die bepaalde karakteristieken delen. De latenteklassenanalyse heeft als doel om aan de hand van een aantal geobserveerde variabelen een achterliggende, niet-geobserveerde variabele te identificeren (Vermunt 2004). Een dergelijke analyse maakt de variatie in patronen van religiositeit zichtbaar aan de hand van verschillende aspecten van het geloof (gedrag, identificatie, opvattingen) en laat zien in hoeverre de verschillende aspecten van religiositeit cumuleren. Daardoor wordt zichtbaar welke vormen van religiositeit vaak samen voorkomen of juist niet.

Uit deze analyse kwam naar voren dat de moslims kunnen worden ingedeeld in een typologie met vijf categorieën (zie tabel 2). De inhoudelijke kenmerken van de categorieën vloeien rechtstreeks voort uit de empirische 
analyse, de hier gepresenteerde labels vanzelfsprekend niet. Bij de typologie van moslims hanteren we alleen religieuze verschillen en overeenkomsten als bron voor de indeling. Hoe deze categorieën zich verhouden tot andere domeinen, bijvoorbeeld op het gebied van moderne of liberale opvattingen, laten we niet tot uitdrukking komen in het label. Etiketten als 'liberale' of 'moderne' moslims (zie bv. Demant 2005; Korf et al. 2007) zijn dus vermeden.

Aan de hand van tabel 2 bespreken we heel beknopt de signatuur van de diverse categorieën van moslims op basis van concrete religieuze kenmerken. De scores op de afzonderlijke items (bijv. bidden, halal eten) schetsen een duidelijk beeld van de kenmerken die bij een bepaalde categorie moslims horen.

Tabel 2 Moslimtypologie naar onderliggende indicatoren, bevolking van 15 jaar en ouder, 2015 (in procenten)

\begin{tabular}{|c|c|c|c|c|c|c|}
\hline & seculier & cultureel & selectief & $\begin{array}{l}\text { vroom, } \\
\text { privaat }\end{array}$ & $\begin{array}{c}\text { strikt, } \\
\text { praktiserend }\end{array}$ & gemiddeld \\
\hline $\begin{array}{l}\text { ten minste wekelijks naar } \\
\text { moskee (\%) }\end{array}$ & 0 & 5 & 45 & 0 & 84 & 38 \\
\hline vijf keer per dag bidden (\%) & 0 & 0 & 0 & 85 & 90 & 61 \\
\hline eet halal (\%) & 57 & 96 & 96 & 99 & 100 & 97 \\
\hline $\begin{array}{l}\text { alle dagen tijdens ramadan } \\
\text { gevast (\%) }\end{array}$ & 24 & 69 & 83 & 90 & 96 & 86 \\
\hline $\begin{array}{l}\text { geloof is belangrijk (\% } \\
\text { (helemaal) mee eens) }\end{array}$ & 6 & 93 & 92 & 97 & 98 & 92 \\
\hline $\begin{array}{l}\text { doet pijn als iemand iets } \\
\text { slechts zegt over mijn geloof } \\
\text { (\% (helemaal) mee eens) }\end{array}$ & 42 & 76 & 77 & 79 & 87 & 80 \\
\hline $\begin{array}{l}\text { leven volgens regels islam } \\
\text { (\% (helemaal) mee eens) }\end{array}$ & 1 & 42 & 57 & 66 & 82 & 65 \\
\hline
\end{tabular}

Bron: SCP (SIM'15)

Voor seculiere moslims heeft het geloof weinig betekenis en wordt het geloof nauwelijks gepraktiseerd. Voor culturele moslims is het geloof wel belangrijk, maar uit zich dit niet in het praktiseren van de rituele gedragingen zoals bidden of moskeebezoek. Selectieve moslims nemen regelmatig deel aan de sociale en rituele praktijken, maar niet zeer frequent. Het geloof neemt voor de vrome, private moslims een zeer belangrijke plaats in en zij bidden bijvoorbeeld veel en de voedselvoorschriften worden nauw gevolgd. Hun religiositeit wordt wel hoofdzakelijk in de privé-situatie beleden, een moskee wordt amper bezocht. Strikt praktiserende moslims zijn zeer actief in de rituele (bidden, moskeebezoek) en culturele (halal eten, ramadan) praktijk. Ook zijn zij het sterkste van mening dat moslims moeten leven volgens de regels van de islam. 


\section{Groot deel van Marokkaanse moslims is vroom of strikt, Turkse moslims meer divers}

Als we kijken naar hoe vaak de hier onderscheiden categorieën van moslims voorkomen bij de diverse groepen zien we dat veruit het grootste deel van de Marokkaanse moslims strikt praktiserend (41\%) of vroom (43\%) is (zie tabel 3). Samengenomen past dus $84 \%$ van hen in de twee categorieën die het geloof het sterkst belijden. Seculiere (2\%) of selectieve (5\%) moslims komen nauwelijks voor bij Marokkaanse moslims.

Bij de Turkse moslims is er meer diversiteit en zijn de twee groepen die het meest strikt zijn (vroom en strikt praktiserend) beduidend kleiner van omvang. De selectieve (27\%) en strikt praktiserende (30\%) groep zijn bij hen ongeveer even groot. Daarnaast is bij elkaar opgeteld ruim een kwart culturele $(21 \%)$ of seculiere $(7 \%)$ moslim. Dus naast de groep van Marokkaanse en Turkse Nederlanders die zich als niet-gelovig beschouwt, is er een kleine groep die zich wel moslim noemt, maar waarvoor het geloof weinig betekenis lijkt te hebben.

Op basis van de Survey Integratie Migranten 2015 kunnen we ook aan de hand van de typologie de diversiteit onder moslims laten zien bij twee andere migrantengroepen waarvan een deel zich als moslim beschouwt ${ }^{8}$, de Surinaamse en Somalische Nederlanders.

De Somalische groep lijkt qua religieuze typering veel op de Marokkaanse groep. De strikt praktiserende (43\%) en vrome moslims (43\%) vormen veruit de grootste groepen. Seculiere of culturele moslims komen bij hen nauwelijks voor. Bij de Surinaamse moslims is de seculiere groep relatief groot (14\%) en de strikt praktiserende groep juist klein (22\%) in vergelijking met de drie andere herkomstgroepen. Tegelijkertijd valt ongeveer de helft van de Surinaamse moslims in een van de twee meer strikte categorieën (vroom of strikt praktiserend).

Tabel 3 Moslimtypologie naar herkomst, bevolking van 15 jaar en ouder, 2015 (in procenten)

\begin{tabular}{lccccc}
\hline & seculier & cultureel & selectief & vroom, privaat & $\begin{array}{c}\text { strikt, } \\
\text { praktiserend }\end{array}$ \\
\hline Turks & 7 & 21 & 27 & 15 & 30 \\
Marokkaans & 2 & 8 & 5 & 43 & 41 \\
Somalisch & 2 & 6 & 5 & 43 & 43 \\
Surinaams $^{\mathrm{a}}$ & 14 & 19 & 17 & 29 & 22 \\
\hline
\end{tabular}

a De typologie is voor Surinaamse moslims bepaald op basis van de jaargangen 2011 en 2015 tezamen om voldoende respondenten te hebben.

Bron: SCP (SIM'11-SIM'15) 


\section{Theoretische verwachtingen over de ontwikkelingen in religiositeit}

Er zijn diverse theorieën over de ontwikkelingen met betrekking tot de rol van religie voor het individu en de bredere samenleving. Deze kunnen helpen bij de duiding van de onderzoeksbevindingen over de ontwikkelingen in religieuze beleving. Op basis van deze theorieën kunnen hypothesen worden afgeleid over hoe de religieuze beleving van moslims zich ontwikkelt en over verschillen tussen bepaalde groepen (bijv. generaties of herkomstlanden) in deze ontwikkelingen. Een kanttekening hierbij is dat dit onderzoek hoofdzakelijk beschrijvend van aard is. Er wordt ingegaan op mogelijke verklaringen (hypothesen) voor de gesignaleerde trends, zonder dat er direct zelf onderzoek is gedaan naar die verklaringen.

\section{Secularisering en assimilatie}

De seculariseringsthese veronderstelt dat naarmate een samenleving moderner wordt, de betekenis van religie zowel individueel als maatschappelijk (institutioneel) afneemt (Berger 1967). Eerder onderzoek liet zien dat christelijk Nederland in rap tempo seculariseert (De Hart 2014). Tegelijkertijd kunnen ontwikkelingen tussen en binnen religieuze groepen anders zijn (De Hart 2014). Ook is het niet zo dat er wereldwijd sprake is van secularisering (De Hart 2014).

Voor veel moslims is het geloof verweven met het herkomstland en de herkomstgroep. Inzichten uit de migratie- en integratieliteratuur kunnen dan behulpzaam zijn bij de verwachtingen over en interpretaties van ontwikkelingen in hun religiositeit. De klassieke assimilatietheorie veronderstelt bijvoorbeeld dat bij een langdurig verblijf in een seculiere context, met een toenemende betrokkenheid en blootstelling aan die omgeving, de religiositeit van migranten afneemt (Alba \& Nee 2003). Na migratie passen mensen zich (deels onbewust) steeds verder aan de ontvangende samenleving aan, zodat in de loop van de tijd het etnisch onderscheid en de daarbij behorende sociale en culturele verschillen geringer worden, of zelfs op den duur verdwijnen. De notie van 'plausibility structure' (geloofwaardigheidsstructuur) (Berger 1967) maakt dat proces inzichtelijk. Om te beklijven moeten opvattingen en overtuigingen door de sociale omgeving worden bevestigd en ondersteund. Opvattingen komen onder druk te staan bij een wisseling van (sociale) omgeving, waarbij er blootstelling is aan andere denkbeelden. Aangezien Nederland over het algemeen als veel meer geseculariseerd beschouwd wordt dan de rest van de wereld, houdt dat voor veel migranten in dat ze terechtkomen in een voor hen ongewoon on-religieuze omgeving (Maliepaard \& 
Gijsberts 2012). De assimilatiehypothese is in de seculiere Nederlandse context - in tegenstelling tot bijvoorbeeld de christelijke context in de Verenigde Staten - dus gelijk aan de seculariseringshypothese.

Op basis van de assimilatie- en seculariseringstheorieën is de verwachting dat de religiositeit onder moslims in Nederland afneemt. Concreet betekent dit dat zowel een steeds groter deel van de Turkse en Marokkaanse Nederlanders zich niet-gelovig noemt, als dat de religieuze beleving onder Turkse en Marokkaanse moslims afneemt.

\section{De opeenvolging van generaties}

Het proces van assimilatie vindt volgens de klassieke assimilatietheoretici niet alleen plaats gedurende de individuele levensloop, maar vindt nadrukkelijk plaats via de opeenvolging van generaties (Warner \& Srole 1945). Volledige assimilatie zou zich volgens hen niet voltrekken binnen één generatie, maar meerdere generaties in beslag nemen. Opeenvolgende generaties van migranten zouden steeds meer overeenkomsten vertonen met de cultuur van de ontvangende samenleving en steeds minder herkenbaar zijn als etnische groep. Assimilatie kan plaatsvinden gedurende meerdere generaties, waarbij het verschil tussen de eerste en tweede generatie doorgaans het grootste is. De eerste generatie is geboren in het land van herkomst, terwijl de tweede generatie geboren en getogen is in de ontvangende samenleving. Leden van deze generatie groeien op in de ontvangende samenleving, gaan er naar school, spreken de taal en worden van kinds af aan blootgesteld aan de cultuur van die ontvangende samenleving. De klassieke assimilatietheorie veronderstelt dat kinderen van migranten - de tweede generatie - sociaal-cultureel steeds meer gaan lijken op de autochtone bevolking. De bijbehorende hypothese is dat de tweede generatie vaker niet gelovig is en hun religieuze beleving kleiner is dan de eerste generatie.

\section{Alternatieven voor de seculariseringsthese: toenemende religionisering}

Het idee dat de seculiere Nederlandse samenleving vanzelf zou leiden tot afnemende religiositeit bij moslims lijkt steeds minder empirische steun te vinden (Maliepaard \& Fleischmann 2011). De verwachtingen over de ontwikkelingen in de religiositeit van migrantengroepen zijn niet eenduidig. De gesegmenteerde assimilatietheorie (Portes \& Zhou 1993) stelt dat er verschillende paden van integratie zijn, waaronder één die gekenmerkt wordt door behoud van culturele waarden en een sterke (etnische) solidariteit. Integratie is geen eenduidig, lineair proces van het loslaten van de etnisch-culturele 
achtergrond. Er kan sprake zijn van een 'etnisch-culturele revitalisering' of een beperkte integratie op bepaalde domeinen.

De assimilatiethese ziet interactie met andersdenkenden en de blootstelling aan andere denkbeelden als belangrijke mechanismes voor (culturele) aanpassing. Als er weinig interactie is met 'andersdenkenden' of blootstelling aan afwijkende denkbeelden is het niet waarschijnlijk dat (religieuze) opvattingen veranderen. In Nederland, zijn de ontmoetingskansen met autochtone Nederlanders afgenomen en is het aantal herkomstgenoten van Turkse en Marokkaanse Nederlanders toegenomen, net als het aanbod van religieuze gebedshuizen (Huijnk \& Andriessen 2016; Maliepaard \& Gijsberts 2012). Ook is er steeds meer ruimte om virtuele, sociale netwerken aan te gaan. Fysieke afstand is dan nauwelijks een belemmering voor de omgang met moslims uit andere woonplaatsen of landen. Er is dus meer ruimte ontstaan om aandacht te blijven geven aan religie en meer mogelijkheid om met gelijkgestemden om te gaan. Wanneer veel mensen van dezelfde groep bij elkaar in de buurt wonen, kan dit ook bevorderlijk zijn voor sociale controle en/of sociale druk om zich te gedragen volgens bepaalde (religieuze of etnische) conventies. Dit geldt bij uitstek voor religieuze groepen, omdat de regels vaak helder zijn en relatief goed controleerbaar (Maliepaard \& Gijsberts 2012). Als de interactie met andersdenkenden beperkt is en de mogelijkheden om invulling en verdieping te geven aan de religieuze beleving groter worden, kan men verwachten dat er juist sprake is van een toenemende religieuze beleving (religionisering) van Turkse en Marokkaanse moslims in Nederland.

\section{Religionisering in een seculiere context}

Het gelovig zijn in een seculiere context kan ook leiden tot juist een toenemende religieuze beleving van de (resterende) gelovigen. In een sterk seculiere omgeving, kan de behoefte voor gelovigen aan een veilige, vertrouwde omgeving, waarin men zichzelf kan zijn, sterk zijn. Deels kan een versterkte religieuze beleving een reactie zijn op het leven in een seculiere en liberale omgeving. Gelovigen zijn in de minderheid en een religieuze levensstijl is allerminst een vanzelfsprekendheid. Dit dwingt gelovigen ertoe zelf actief het geloof te onderhouden, om te voorkomen dat het geloof verslapt (Beekers 2015). In een seculiere samenleving is het voor gelovigen van belang, zelfs noodzakelijk, om het eigen geloof te blijven voeden en op te bouwen (Roeland et al. 2010). Dit geldt voor moslims, maar overigens net zo voor christenmigranten of bepaalde orthodoxe protestante gemeenschappen in Nederland (De Hart 2014). 
Deze toename in religiositeit kan nog sterker zijn wanneer de ervaringen (met niet-moslims) binnen de Nederlandse samenleving als negatief worden ervaren. Veel moslims ervaren het klimaat in Nederland ten aanzien van hen en hun geloof ook als zeer negatief (zie bijv. Van der Valk 2017; Andriessen et al. 2014; Andriessen 2016) en hebben het gevoel er niet bij te (mogen) horen. Volgens de rejection-identification hypothese (Branscombe et al. 1999) kan het negatief ervaren maatschappelijke klimaat ertoe leiden dat men zich terugtrekt en/of dat de banden met de eigen religieuze gemeenschap worden aangehaald (religieuze revitalisering). De ervaring van uitsluiting, negatieve vooroordelen en discriminatie bevorderen de groepsidentificatie (Branscombe et al. 1999; Jetten et al. 2001) en kan een motivatie vormen voor een verscherpte profilering van de eigen moslimidentiteit, in woord en in gebaar (bijv. het dragen van een hoofddoek) (De Hart 2012; De Koning 2008). Dit geldt mogelijk nog het meest voor de Marokkaanse groep; de beeldvorming over hen is het meest negatief, zij zijn de meest gestigmatiseerde migrantengroep in Nederland.

\section{De individualiseringsthese}

De dichotomie secularisering versus religionisering is te simpel. Het is (vanzelfsprekend) ook mogelijk dat er 'gemengde' ontwikkelingen zijn. Zo stelt de individualiseringsthese dat moslims - met name jongeren en/of van de tweede generatie ${ }^{9}$ - in toenemende mate zelf op zoek gaan naar de betekenis en invulling van hun geloof en volgen zij niet klakkeloos wat de imam of hun ouders hun voorschrijven (De Koning 2008; Noor 2018; Wagemakers \& De Koning 2015). Individualisering verwijst dan naar het pad waarlangs iemand tot zijn religieuze beleving komt en niet naar de concrete wijze waarop de religie wordt beleden. Voor een deel van de moslims kan deze persoonlijke zoektocht leiden tot secularisering, maar tegelijkertijd kan het bij een ander deel zo zijn dat religie juist aan belang wint. De hernieuwde interesse voor de islam - het opnieuw definiëren van hun religie - is in eerste instantie een individuele aangelegenheid. Voor een deel heeft deze transformatie betrekking op de verbetering van de persoonlijke band met God en het streven naar religieuze groei (Noor 2018). Tegelijkertijd heeft het een sterk sociaal karakter. De individuele verdieping kan leiden tot een collectieve vorm van religieuze expressie; het motiveert om andere leden van de religieuze gemeenschap te ontmoeten en kennis en ervaringen uit te wisselen.

Roy (2004) stelt daarnaast dat voor de tweede generatie niet zozeer het belang van het geloof afneemt, maar dat er zich binnen die generatie steeds meer een individuele islam zal ontwikkelen, die minder sterk wordt beïnvloed 
door de culturele interpretaties uit het herkomstland. Anderen zien ook dat de tweede generatie in toenemende mate los komt van de etnische of lokale wortels en zich vooral verbonden voelt met de wereldwijde islamitische gemeenschap (de ummah) (De Koning 2008).

\section{Ontwikkelingen in de religieuze beleving van Turkse en Marokkaanse Nederlanders}

Hoe heeft de religiositeit van Turkse en Marokkaanse Nederlanders zich ontwikkeld? Allereerst kijken we naar het deel dat zich moslim beschouwt (zie tabel 4). Tussen 2006 en 2015 is onder zowel de Turkse eerste als tweede generatie het aandeel dat zich moslim beschouwt afgenomen (tabel 4). Bij de Marokkaanse groep zien we voor zowel de hele groep als de twee afzonderlijke generaties geen afname in religieuze zelftoekenning tussen 2006 en 2015. Wel is het zo dat tussen 2011 en 2015 het aandeel tweede generatie Marokkaanse Nederlanders dat zich als moslim ziet wat is afgenomen.

Tabel 4 Aandeel dat zich moslim beschouwt, naar herkomst en generatie, 2006-2015 (in procenten)

\begin{tabular}{lcccccc}
\hline & $\begin{array}{c}\text { Marokkaans, } \\
\text { totaal }\end{array}$ & $\begin{array}{c}\text { Marokkaans, } \\
\text { le generatie }\end{array}$ & $\begin{array}{c}\text { Marokkaans, } \\
\text { 2e generatie }\end{array}$ & $\begin{array}{c}\text { Turks, } \\
\text { totaal }\end{array}$ & $\begin{array}{c}\text { Turks, } \\
\text { 1e generatie }\end{array}$ & $\begin{array}{c}\text { Turks, } \\
\text { 2e generatie }\end{array}$ \\
\hline 2006 & 95 & 95 & 93 & 93 & 93 & 90 \\
2011 & 97 & 98 & 96 & 94 & 96 & 91 \\
2015 & 94 & 96 & 91 & 86 & 90 & 82 \\
\hline
\end{tabular}

Bron: scp/cbs (sim'06/'11/'15)

Toename van de twee moslimcategorieën waarvoor de religieuze beleving het sterkste is

De twee categorieën die qua gedrag en opvattingen het meest gelovig zijn (de vrome en strikt praktiserende moslims) zijn sinds 2006 in omvang toegenomen onder zowel de Turkse (van 37\% naar 45\%) als Marokkaanse groep (van $77 \%$ naar 84\%). Bij de Turkse en Marokkaanse moslims is de groep van culturele moslims sinds 2006 gestaag afgenomen. Er is onder zowel Turkse als Marokkaanse moslims geen verandering in het (kleine) aandeel seculiere moslims. De hier gesignaleerde ontwikkelingen gelden globaal ook voor subgroepen, zoals de tweede generatie, jongeren (15-24 jaar), mannen en vrouwen en hoger opgeleiden. Het beeld per subgroep is in grote lijnen identiek. De groep seculiere moslims is vrij stabiel en klein van omvang. Het aandeel culturele moslims neemt bij alle groepen door de tijd af. Bij alle groepen is er 
globaal de ontwikkeling naar een grotere wordende groep moslims die vroom of strikt is.

\section{Ontwikkelingen in specifieke gedragingen en houdingen}

Als we kijken naar de ontwikkelingen op de diverse religieuze indicatoren zien we dat het bidden onder beide generaties van zowel de Turkse als Marokkaanse moslims is toegenomen. Bij de Turkse moslims is de afgelopen tien jaar het moskeebezoek bij beide generaties toegenomen. Bij Marokkaanse moslims is er op dit vlak geen duidelijke ontwikkeling. Bij de Marokkaanse moslims is het deel dat halal eet iets gegroeid, bij de Turkse moslims is dit gelijk gebleven. Bij zowel Turkse als Marokkaanse moslims is het deel dat alle dagen vast tijdens de ramadan afgenomen, al is met name bij de Marokkaanse groep de afname gering en vast het overgrote deel dagelijks.

Het dragen van een hoofddoek is in tien jaar tijd sterk toegenomen bij de Marokkaanse moslima's. Droeg in 2006 minder dan twee derde (64\%) een hoofddoek, in 2015 is dit ruim driekwart (78\%). Deze ontwikkeling zien we ook terug bij de tweede generatie, jongeren en hoogopgeleiden. Bij de Turkse moslima's zien we tussen 2006 en 2015 nauwelijks een ontwikkeling in het dragen van een hoofddoek. Ten slotte zijn er geen eenduidige ontwikkelingen door de tijd heen in de religieuze opvattingen, bijvoorbeeld ten aanzien van de rol van het geloof in de politiek, gemengd huwen of het leven volgens de regels van de islam. Ook is de religieuze identificatie tussen 2006 en 2015 min of meer gelijk gebleven. Het moslim-zijn was in 2006 belangrijk voor de Turkse en Marokkaanse moslims en dat was in 2015 nog zo.

\section{Slotbeschouwing en discussie}

Voor veel moslims is het geloof onverminderd belangrijk. Een zeer groot deel van de Turkse en Marokkaanse Nederlanders beschouwt zich als moslim. Voor bijna alle moslims, de kleine groep van seculiere moslims daargelaten, neemt het geloof een belangrijke plaats in. Niettemin schuilt onder deze hoofdstroom diversiteit. Deze pluriformiteit loopt onder andere via de verschillen tussen herkomstgroepen. Marokkaanse en Somalische moslims zijn bijvoorbeeld op veel vlakken, met name als het gaat om de praktisering, religieuzer dan de Turkse of Surinaamse moslims. Van de Marokkaanse moslims past een zeer groot deel in de twee categorieën die het meest gelovig zijn: de vrome en strikt praktiserende moslims. Bij de Turkse moslims is er meer diversiteit op dit vlak. Ook de moslimtypologie laat religieuze diversiteit onder 
moslims in Nederland zien. Bepaalde gedragingen en opvattingen concentreren zich sterker binnen bepaalde groepen moslims, en deze groepen wijken ten opzichte van elkaar af op hun houdingen en de posities die zij innemen in de samenleving. ${ }^{10}$

\section{Individualisering, lichte secularisering en religionisering}

De religieuze beleving van moslims is in beweging. De richting waarin is niet eenduidig. Er is bij de Turkse Nederlanders licht sprake van secularisering in de zin van dat het deel dat zich als niet-gelovig beschouwt, alhoewel nog steeds relatief klein, gegroeid is. Ook is het zo dat op veel terreinen de tweede generatie wat minder religieus is dan de eerste. Een iets groter deel is niet-gelovig, bidt minder vaak, draagt minder vaak een hoofddoek en bij de Marokkaanse tweede generatie is het moskeebezoek lager. Ook ander onderzoek liet zien dat onder jongeren van 15 jaar de religieuze beleving minder sterk is dan bij hun ouders (De Hoon \& Van Tubergen 2014).

Deze (lichte) vormen van secularisering - zowel de ontwikkeling in de tijd als het verschil tussen de generaties - passen in het beeld van de secularisering- en assimilatiehypothese. Tegelijkertijd zijn adolescenten met een moslimachtergrond aanzienlijk religieuzer dan hun leeftijdsgenoten (De Hoon \& Van Tubergen 2014; Van Tubergen \& Sindradottir 2011). Ook voor een groot deel van de tweede generatie is het geloof zeer belangrijk en neemt het belang van geloof juist toe (zie ook Huijnk et al. 2015).

Tevens duiden andere ontwikkelingen niet op secularisering. Bij de Marokkaanse Nederlanders zien we niet dat het deel dat zich moslim noemt kleiner is dan tien jaar eerder. Onder zowel Turkse als Marokkaanse moslims is er sprake van toenemende religiositeit. Bij Turkse moslims zijn bijvoorbeeld bij beide generaties het moskeebezoek en het bidden toegenomen. Bij de Marokkaanse moslims geldt dit voor het bidden, het halal eten en het dragen van een hoofddoek. Het dragen van een hoofddoek is bij jonge en hoogopgeleide Marokkaanse moslima's in kort tijdsbestek relatief sterk toegenomen. De bevindingen passen binnen de these dat secularisering ertoe kan leiden dat de religieuze betrokkenheid van de (resterende) gelovigen sterker wordt.

We nemen dus twee schijnbaar tegengestelde bewegingen waar van lichte secularisering van met name Turkse Nederlanders en toenemende religieuze beleving van Turkse en Marokkaanse moslims. De verwachtingen over religieuze veranderingen (na migratie) waren ook geenszins eensluidend. De theorieën beschrijven enerzijds factoren die naar verwachting samengaan met sterkere religiositeit, zoals de aanwezigheid van herkomstgenoten in 
de buurt, een groter aanbod van moskeeën in de buurt en de ervaren discriminatie. Anderzijds zijn er factoren die samen kunnen gaan met minder sterke religiositeit, zoals het vormen van contacten met (seculiere) autochtone Nederlanders, het volgen van een (hogere) opleiding en het in toenemende mate identificeren met Nederland. De complexe interactie van dit soort factoren bepaalt uiteindelijk mede de religieuze ontwikkeling van een groep. Tegelijkertijd kan deze "optelsom" voor individuen of subgroepen heel anders uitpakken. In die zin is het niet vreemd dat er meerdere ontwikkelingen waar te nemen zijn; herkomstgroepen zijn niet homogeen en individuen hebben (vanzelfsprekend) meerdere sociale identiteiten.

\section{Blootstelling aan wiens denkbeelden?}

Begin deze eeuw was de verwachting nog veel nadrukkelijker dat processen van secularisatie zich ook bij moslims zouden gaan voordoen. In Moslim in Nederland (2004) schreven Phalet en Ter Wal (p. 15) bijvoorbeeld "Kort samengevat wijst een aantal factoren in de richting van een dalende trend van het belang van de islam, waarvan het aannemelijk lijkt dat die zich ook in de toekomst zal doorzetten". Deze verwachting is nauwelijks uitgekomen en wordt dus ook niet bevestigd door ons onderzoek. Het idee achter de secularisatiethese is dat bij een langdurig verblijf in een seculiere context de religiositeit van migranten afneemt. De vraag kan gesteld worden hoe seculier de directe sociale omgeving van veel moslimjongeren is. Sociale netwerken zijn veelal gescheiden, net als de (sociale) media waar men zich op richt (Huijnk et al. 2015). De onderlinge beeldvorming van moslims en niet-moslims is veelal niet positief; dit staat contact en de bereidheid om kennis te nemen van elkaars denkbeelden in de weg. De negatieve oordelen over de islam en moslims vanuit de Nederlandse maatschappelijke omgeving stimuleren het aanhalen van de banden binnen de herkomstgroep en het onderlijnen van de moslimidentiteit. De afwerende houding vanuit de Nederlandse samenleving maakt het geloof, de moslimidentiteit en het behoren tot een gemeenschap extra aantrekkelijk. De negatieve beeldvorming kan een stimulans zijn om zich te verdiepen in de kennis over de islam. Wat we zien is dat de religieuze beleving van de Marokkaanse groep - de meest gestigmatiseerde migrantengroep in Nederland - op een aantal vlakken groter is dan die van de Turkse groep. Dit kan gezien worden als een bevestiging van de rejection-identification-hypothese. Tegelijkertijd moeten we terughoudend zijn met deze conclusie. Allereerst verschillen de Turkse en Marokkaanse groep op nog veel meer aspecten dan alleen de mate van stigmatisering, zoals de rol van de islam in het herkomstland, het belang van de nationale identiteit en de etnische groepsbanden. Bovenal, hebben 
we in dit artikel de rejection-identification-hypothese niet direct getoetst. Daarnaast is de empirische, kwantitatieve ondersteuning voor de gedachte dat het negatieve maatschappelijke klimaat onder moslims leidt tot religieuze revitalisering tot nu toe wisselend (Maliepaard \& Gijsberts 2012).

\section{Toenemende religiositeit juist als reactie op pluralisme}

Beide (tegengestelde) bewegingen - secularisering en een toename in de religieuze beleving van moslims - passen bij het idee dat er in de westerse, seculiere en plurale samenleving sprake is van een individualisering van het geloof. Deels kan een versterkte religieuze beleving een reactie zijn op het leven in een seculiere en liberale omgeving. Gelovigen zijn in de minderheid en een religieuze levensstijl is allerminst een vanzelfsprekendheid. Om te voorkomen dat het geloof verslapt worden gelovigen gedwongen het geloof actief te onderhouden (Beekers 2015). Het leven in een westerse samenleving met opvattingen en gedragingen die niet stroken met wat het geloof voorschrijft, lijkt bij sommige moslimjongeren de vastberadenheid te stimuleren om dicht bij dat geloof te blijven (Huijnk et al. 2015).

Het is niet alleen de confrontatie met seculiere denkbeelden die de zoektocht naar een diepere waarheid of processen van versterkte religiositeit bij jongeren stimuleert (Roeland et al. 2010). Ook de religieuze of culturele diversiteit binnen de gemeenschap kan hieraan bijdragen. Zoals gezegd plaatst een deel van de jongeren vraagtekens bij de wijze waarop hun ouders het islamitisch geloof vormgeven (Roy 2004). De islam van hun ouders en familie wordt gezien als gebaseerd op traditie, gewoonte en cultuur in plaats van op de ware islam (De Koning 2008). Meer algemeen kan de confrontatie met de verschillende invullingen van het geloof naar herkomstland en/of tussen religieuze stromingen resulteren in een zoektocht naar de 'echte' islam die losstaat van plaatselijke culturele invullingen (deculturalisering).

Een meer persoonlijke, individualistische zoektocht naar de ware islam kan ertoe leiden dat jongeren juist strenger in de leer worden dan hun ouders of omgeving ooit geweest zijn (De Koning 2008; Roeland et al. 2010). Het kan dan een proces zijn waarbij men zich zowel afzet tegen de ouders, die het geloof in hun perceptie niet op een zuivere manier belijden, als tegen een seculiere omgeving die afwijzend staat ten aanzien van de islam. Voor religieuze verdieping of zoektochten is het internet een bijna onbeperkte bron van informatie en sociale contacten. Virtuele contacten gaan dwars door grenzen van voordeuren, schooldeuren, gemeenten of landen heen. Het geloof en het zich deelgenoot voelen van de islamitische ummah kan een gevoel van geborgenheid en een sterk groepsgevoel geven. 


\section{Ontwikkelingen in breder verband: religieuze revitalisering bij jonge gelovigen in Nederland}

De toename in de religieuze beleving bij moslims in Nederland staat niet op zichzelf. Sinds de jaren zeventig is er binnen een grote (geografische) diversiteit aan moslimlanden een (her)opleving van religieuze waarden, identificatie en participatie (Carvalho 2009). Binnen westerse landen - waar moslims een minderheid vormen - worden er ontwikkelingen van 'deculturalisering' waargenomen, met name bij de tweede generatie. Zij zijn in toenemende mate op zoek naar een 'pure' beleving van de islam, ontdaan van de specifieke etnische of religieuze aspecten uit het herkomstland (Naber 2005; Ali 2018; Roy 2004; Lawrence \& Vaisse 2006).

In vergelijking met ontwikkelingen bij andere religieuze groepen in Nederland zijn er zowel verschillen als overeenkomsten. Onder de christelijke groepen is er duidelijk sprake van secularisering: de conclusie in de God in Nederland studie van 2016 is dat God steeds verder uit onze samenleving verdwijnt en dat Nederland geen christelijke natie meer is. Het kerkbezoek daalt hard, het geloof in een persoonlijke God is sterk afgenomen (Bernts \& Berghuijs 2016). Bij de katholieken is sprake van een dubbele secularisering: niet alleen daalt het aantal katholieke kerkleden, maar bovendien participeren zij steeds minder in geloof en kerk. Bij de protestantse kerken is de secularisatie minder sterk. Weliswaar daalt ook het ledental van de Protestantse Kerk in Nederland (PKN), maar kerkgang en geloof blijven gelijk of dalen slechts beperkt (Bernts \& Berghuijs 2016). Het onversneden christendom is vooral ook te vinden bij de kleine (orthodoxere) protestantse kerken van bijvoorbeeld de bevindelijk gereformeerden of de evangelische gelovigen (Bernts \& Berghuijs 2016).

Tegelijkertijd is er onder jonge gelovigen een algemene tendens naar een sterkere binding met het geloof en vormen van orthodoxie (De Hart 2014). De zoektocht van jonge moslims naar manieren om hun geloof vorm te geven in een pluralistische en grotendeels seculiere samenleving vertoont overeenkomsten met die van andere jonge gelovigen in de Nederlandse samenleving, zoals de orthodox-protestanten (bijv. de evangelicalen) of katholieken. De behoefte aan een veilige, vertrouwde omgeving waarin men zichzelf kan zijn, is niet anders voor moslims dan voor orthodox-protestantse gemeenschappen of christenmigranten. Christenen en moslims nemen op dit punt een vergelijkbare positie in, die overeenkomstige worstelingen oplevert. De religieuze beleving kan vorm krijgen in netwerken van gelijkgestemden, die aan hen steun bieden, hun geloof bevestigen en hen stimuleren om het ware geloof na te streven. Zowel christenen als moslims gebruiken online gemeenschappen 
om informatie uit te wisselen, religieuze identiteiten te vormen en te participeren in collectieve online rituelen (Roeland et al. 2010).

\section{Discussie}

Om ontwikkelingen zoals secularisering of religionisering goed in kaart te brengen, moet er niet alleen aandacht zijn voor de praxis, maar ook voor andere kanten van de religiositeit (Ajouaou 2015). Ondanks dat we diverse kanten van de religiositeit hebben belicht, bleven er vanzelfsprekend onderwerpen onaangeroerd, zoals bijvoorbeeld specifieke vragen over geloofsinhoud en -voorstellingen (De Koning 2012; Ajouaou 2015). Ook stelt Ajouaou (2015) dat uitwendige religiositeit geen indicatie hoeft te zijn voor afwezigheid van secularisatie: het hoeft niet altijd wat te zeggen over de innerlijke motivatie, persoonlijke opvattingen en religieuze denkbeelden. Juist daarom is het van belang om de verschillende religieuze indicatoren in samenhang met elkaar te zien en is het niet zo dat in dit artikel één kenmerk doorslaggevend is voor het bepalen van een ontwikkeling. Tegelijkertijd zien we een sterke samenhang tussen de diverse religieuze opvattingen en gedrag.

Het onderzoek is cross-sectioneel uitgevoerd - in de verschillende jaren zijn niet dezelfde personen ondervraagd - hierdoor is het wel mogelijk om op het niveau van de groep inzicht te krijgen in ontwikkelingen, maar niet of en hoe ontwikkelingen binnen individuen hebben plaatsgevonden. Terughoudendheid met de interpretatie van de gegevens is dus op zijn plaats. Dit geldt ook met betrekking tot de mogelijke oorzaken van de hier gesignaleerde ontwikkelingen. Of die te maken hebben met een internationale trend naar een heropleving van religieuze waarden bij moslims, met de interactie tussen seculieren en gelovigen in Nederland of bijvoorbeeld met generatieconflicten is dus niet met zekerheid te zeggen.

Deze studie bevestigt het beeld van andere studies, met name kwalitatief van aard, dat het geloof voor veel moslims een belangrijke plaats in hun leven inneemt en dat er verschillende ontwikkelingen - zowel secularisering als een toename in de religieuze beleving van moslims - zichtbaar zijn. Het is niet eenduidig wat de toenemende religiositeit betekent voor de positie van moslims in de Nederlandse samenleving. Toenemende religiositeit kan positief uitwerken voor bijvoorbeeld de geestelijke gezondheid, prosociaal gedrag of de banden met leden binnen de herkomstgroep, maar lijkt tegelijkertijd de sociaal-culturele afstand tussen moslims en niet-moslims in Nederland te vergroten (Huijnk 2018). De perceptie van (groter wordende) culturele verschillen tussen moslims en niet-moslims werkt door in de onderlinge beeldvorming. Hierdoor worden scheidslijnen en groepsgrenzen dieper getrokken 
(Huijnk et al. 2015). Moslims worden door een deel van de niet-moslims gezien als 'de ultieme ander' (De Koning 2016). Alhoewel de Nederlandse identiteit en de moslimidentiteit elkaar geenszins hoeven uit te sluiten, lijkt voor veel moslims hun geloof de belangrijkste sociale identiteit te zijn (Huijnk et al. 2015). Een toename in religiositeit en de daarmee gepaard gaande grotere sociaal-culturele afstand lijken de leefwerelden van moslims en niet-moslims alleen maar sterker van elkaar te scheiden.

\section{Noten}

1 Deze cijfers zijn gebaseerd op de Enquête Beroepsbevolking (EBB). Een kanttekening bij deze cijfers is dat ze betrekking hebben op personen van 15 jaar en ouder. Onder kinderen die jonger zijn dan 15 jaar is het zeer aannemelijk dat het aandeel moslims groter is. Ongeveer de helft van bijvoorbeeld de Turkse en Marokkaanse Nederlanders is van de tweede generatie en deze generatie is gemiddeld pas 18 jaar oud. Daarnaast bereiken algemene surveys vaak een selectieve groep van migranten, met name hoogopgeleide migranten die de Nederlandse taal goed beheersen Het is aannemelijk dat met name moslims van de eerste generatie zijn ondervertegenwoordigd in een algemene survey zoals de EBB. Het is dus waarschijnlijk dat het aandeel moslims in de gehele Nederlandse bevolking groter is dan $6 \%$.

2 Het Sociaal en Cultureel Planbureau (SCP) publiceerde in juni 2018 De religieuze beleving van moslims in Nederland (Huijnk 2018). Dit artikel is een bewerking van dit rapport. Deze publicatie is de derde scp-studie die zich expliciet richt op moslims in Nederland. Het is tevens het eerste deel van een reeks van studies naar religie en spiritualiteit van het SCP. Centraal hierin staat de ontwikkeling van verschillende religies en levensbeschouwingen. In het tweede deel zal een (voornamelijk) kwantitatief overzicht worden gegeven van de meer recente ontwikkelingen in christelijk Nederland, waarbij ook de christenmigranten aan de orde komen. Het derde deel uit de reeks zal in 2019 verschijnen en vooral ingaan op de verbreiding en impact van niet kerkelijk gebonden vormen van spiritualiteit en op de levensbeschouwing van buitenkerkelijken en niet-gelovigen.

3 De tweede generatie betreft de kinderen van migranten (de eerste generatie).

4 Zie voor meer achtergrondinformatie over de onderzoeken de veldwerkverslagen van Andriessen \& Kappelhof (2015), Korte \& Dagevos (2011) en Dagevos et al. (2007).

5 Om stilistische reden spreken we in het rapport niet telkens over Turks-Nederlandse of Marokkaans-Nederlandse moslims, maar over Turkse en Marokkaanse moslims.

6 Roex et al. (2010) lieten zien dat - volgens hun definitie - ongeveer $8 \%$ van de moslims kan worden gezien als streng orthodox. De mate van orthodoxie was daarbij vastgesteld op basis van bijvoorbeeld het luisteren naar niet-religieuze muziek, het aanwezig zijn op plekken waar alcohol wordt gedronken, het uitstellen van het verplichte gebed of het aanwezig zijn op plekken waar mannen en vrouwen gezamenlijk aanwezig zijn. Op dit soort aspecten is in het huidige onderzoek dus niet ingegaan.

7 Niet alle hier genoemde cijfers staan gepresenteerd in de tabellen. Deze staan wel in het rapport zelf. In de tekst worden alleen verschillen (tussen groepen of in de tijd) expliciet benoemd als ze significant zijn.

8 Van de Surinaamse moslims beschouwt ongeveer 9\% zich moslim, bij de Somalische Nederlanders is dit $95 \%$. 
9 Het betreft hier feitelijk kinderen van migranten $\left(2^{\mathrm{e}}\right.$ generatie-personen met een migratie-achtergrond) die zich moslim noemen en dus niet moslims van de tweede generatie.

10 In dit artikel gaan we - in tegenstelling tot het onderliggende rapport - niet in op de vraag hoe de verschillende categorieën van moslims zich verhouden tot de nietreligieuze domeinen en posities in de samenleving.

\section{Literatuur}

Ajouaou, M. (2015),

Gesluierde secularisatie onder hedendaagse Nederlandse moslims, in: Religie Q Samenleving, 10 (2), 177-191.

Alba, R. \& V. Nee (2003),

Remaking the American mainstream. Assimilation and contemporary immigration, Cambridge (Mass.): Harvard University Press.

Ali, M. (2018),

Young Muslim America: Faith, Community, and Belonging, New York: Oxford University Press.

Andriessen, I. (2016),

De multi-etnische samenleving onder druk?, in: Huijnk, W. \& I. Andriessen (red.), Integratie in zicht. De integratie van migranten in Nederland op acht terreinen nader bekeken, Den Haag: Sociaal en Cultureel Planbureau, 243-281.

Andriessen, I., H. Fernee \& K. Wittebrood (2014),

Ervaren discriminatie in Nederland, Den Haag: Sociaal en Cultureel Planbureau.

Andriessen, I. \& J. Kappelhof (2015),

Survey Integratie Migranten 2015, Den Haag: Sociaal en Cultureel Planbureau.

Beekers, D. (2015),

Precarious piety. Pursuits of faith among young Muslims and Christians in the Netherlands, (dissertatie), Amsterdam: Vrije Universiteit Amsterdam.

Berger, P. (1967),

The sacred canopy, New York: Doubleday.

Bernts, T. \& J. Berghuijs (2016),

God in Nederland 1966-2015, Utrecht: Ten Have.

Branscombe, N., M. Schmitt \& R. Harvey (1999),

Perceiving pervasive discrimination among African-Americans. Implications for group identification and well-being, in: Journal of Personality and Social Psychology,

$77(1), 135-149$.

Carvalho, J. (2009),

A theory of the Islamic revival, Oxford: Oxford University (Department of Economics

Discussion Paper Series 424). 
Connor, P. (2008),

Increase or decrease? The impact of the international migratory event on immigrant religious participation, in: Journal for the Scientific Study of Religion, 47 (2), 43-257.

Dagevos, J., M. Gijsberts, J. Kappelhof \& M. Vervoort (2007),

Survey integratie minderheden 2006, Den Haag: Sociaal en Cultureel Planbureau.

Demant, F. (2005),

'Islam is inspanning.' De beleving van de islam en de sekseverhoudingen bij Marokkaanse jongeren in Nederland, Utrecht: Verwey-Jonker Instituut.

Doorn, M. van (2011),

Sociaal-culturele positie en religie, in: Dourleijn, E. \& J. Dagevos (red.), Vluchtelingengroepen in Nederland. Over de integratie van Afghaanse, Iraakse, Iraanse en Somalische migranten, Den Haag: Sociaal en Cultureel Planbureau, 165-189.

Ebaugh, H., J. O’Brien \& J. Chafetz (2000),

The social ecology of residential patterns and membership in immigrant churches, in: Journal for the Scientific Study of Religion, 39 (1), 107-117.

Hackett, C., M. Stonawski, M. Potančokova, B. Grim \& V. Skirbekk (2015),

The future size of religiously affiliated and unaffiliated populations. in: Demographic Research, 32 (27), 829-842.

Hart, J. de (2012),

Wat je gelooft dat ben je zelf. Een paar godsdienstsociologische overwegingen, in: Maliepaard, M. \& M. Gijsberts (red.), Moslim in Nederland 2012, Den Haag: Sociaal en Cultureel Planbureau, $169-176$.

Hart, J. de (2014),

Geloven binnen en buiten verband. Godsdienstige ontwikkelingen in Nederland, Den Haag: Sociaal en Cultureel Planbureau.

Hoon, S. de \& F. van Tubergen (2014),

The religiosity of children of immigrants and natives in England, Germany, and the Netherlands. The role of parents and peers in class, in: European Sociological Review, $30(2), 194-206$.

Huijnk, W. (2018),

De religieuze beleving van moslims in Nederland. Diversiteit en verandering in beeld, Den Haag: Sociaal en Cultureel Planbureau.

Huijnk, W. \& I. Andriessen (2016),

Integratie in zicht? De integratie van migranten in Nederland op acht terreinen nader bekeken, Den Haag: Sociaal en Cultureel Planbureau.

Huijnk, W., J. Dagevos, M. Gijsberts \& I. Andriessen (2015),

Werelden van verschil, Den Haag: Sociaal en Cultureel Planbureau. 
Huijnk, W., I. Andriessen \& L. Sterckx (2015),

Opvattingen over religieus geïnspireerd geweld en IS onder Turkse en Marokkaanse Nederlanders, Den Haag: Sociaal en Cultureel Planbureau.

Jetten, J., N. Branscombe, M. Schmitt \& R. Spears (2001),

Rebels with a cause. Group identification as a response to perceived discrimination from the mainstream, in: Personality and Social Psychology Bulletin, 27 (9), 1204-1213.

Koning, M. de (2008),

Zoeken naar een 'zuivere' islam. Religieuze beleving en identiteitsvorming van MarokkaansNederlandse moslims, Amsterdam: Bert Bakker.

Koning, M. de (2012),

Moslims tellen. Reflectie op onderzoek naar islam, moslims en secularisering in Nederland, in: Maliepaard, M. \& M. Gijsberts, Moslim in Nederland 2012, Den Haag: Sociaal en Cultureel Planbureau, 160-168.

Koning, M. de (2016),

Een ideologische strijd tegen de islam. Fortuyns gedachtegoed als scharnierpunt in de racialisering van moslims, Uithoorn: Karakter Uitgevers B.V.

Koning, M. de, J. Wagemakers \& C. Becker (2014),

Salafisme. Utopische idealen in een weerbarstige praktijk, Almere: Parthenon.

Korf, D.J., B. Yesilgoz, T. Nabben \& M. Wouters (2007),

Van vasten tot feesten. Leefstijl, acceptatie en participatie van jonge moslims, Utrecht: Forum/Uitgeverij Ger Guijs.

Korte, K. \& J. Dagevos (2011),

Survey Integratie Minderheden 2011, Den Haag: Sociaal en Cultureel Planbureau.

Lawrence, J. \& J. Vaisse (2006),

Integrating Islam: Political and Religious Challenges in contemporary France, Washington DC: Brookings Institution Press.

Maliepaard, M. \& F. Fleischmann (2011),

Van migrantenstudies naar moslimstudies? Een beschouwing op het migratieonderzoek in het Nederlands taalgebied, in: Migrantenstudies, 27 (2), 155-164.

Maliepaard, M. \& M. Gijsberts (2012),

Moslim in Nederland 2012, Den Haag: Sociaal en Cultureel Planbureau.

Naber, N. (2005),

Muslim First, Arab Second: A Strategic Politics of Race and Gender, in: The Muslim World, 95 (4), 479-495.

Noor, S. (2018),

Het geloof van moslimvrouwen in Nederland en België, (dissertatie), Nijmegen: Radboud Universiteit. 
Phalet, K. \& J. ter Wal (2004),

Moslim in Nederland, Den Haag: Sociaal en Cultureel Planbureau.

Portes, A. \& M. Zhou (1993),

The new second generation. Segmented assimilation and its variants, in: The Annals of the American Academy of Political and Social Science, 53 (1), 74-96.

Roeland, J., S. Aupers, D. Houtman, M. de Koning \& I. Noomen (2010),

Zoeken naar zuiverheid. Religieuze purificatie onder jonge new-agers, evangelicalen en moslims, in: Sociologie, 6 (2), 11-29.

Roex, I., S. van Stiphout \& J. Tillie (2010),

Salafisme in Nederland. Aard, omvang en dreiging, Amsterdam: Instituut voor Migratieen Etnische Studies, Universiteit van Amsterdam.

Roy, O. (2004),

Globalised Islam. The search for a new Ummah, London: Hurst Publishers.

Schmeets, H. (2015),

Religieuze betrokkenheid en sociale samenhang, in: Schmeets, H. (red.), Sociale samenhang. Wat ons bindt en verdeeld, Den Haag/Heerlen/Bonaire: Centraal Bureau voor de Statistiek, 169-181.

Stark, R. \& C. Glock (1968),

American piety. The nature of religious commitment, Berkeley/Los Angeles: University of California Press.

Sunier, T. (2009),

Beyond the domestication of Islam. A reflection on research on Islam in European societies, Amsterdam: Vrije Universiteit.

Tubergen, F. van \& J. Sindradottir (2011),

The religiosity of immigrants in Europe. A cross-national study, in: Journal for the Scientific Study of Religion, 50 (2), 272-288.

Valk, I. van der \& P. Tornberg (2017),

Monitor moslimdiscriminatie. Derde rapportage, Amsterdam: IMES.

Vermunt, J. (2004),

Toepassingen van latente klasse analyse in sociaal wetenschappelijk onderzoek, in: Sociale Wetenschappen, 47(1), 2-14.

Wagemakers, J. \& M. de Koning (2015),

Islam in verandering. Vroomheid en vertier onder moslims binnen en buiten Nederland, Almere: Parthenon.

Warner, W.L. \& L. Srole (1945),

The social systems of American ethnic groups, New Haven, ct: Yale University Press. 